\title{
Coleopteran and Lepidopteran Hosts of the Entomopathogenic Genus Cordyceps sensu lato
}

\author{
Bhushan Shrestha, ${ }^{1}$ Eiji Tanaka, ${ }^{2}$ Min Woo Hyun, ${ }^{3}$ Jae-Gu Han, ${ }^{3}$ Chang Sun Kim, ${ }^{4}$ \\ Jong Won Jo, ${ }^{4}$ Sang-Kuk Han, ${ }^{4}$ Junsang $\mathrm{Oh},{ }^{5}$ and Gi-Ho Sung ${ }^{1}$ \\ ${ }^{1}$ Institute for Bio-Medical Convergence, International St. Mary's Hospital and College of Medicine, Catholic Kwandong University, \\ Incheon 404-834, Republic of Korea \\ ${ }^{2}$ Environmental Science, Ishikawa Prefectural University, 1-308 Suematsu, Nonoichi, Ishikawa 921-8836, Japan \\ ${ }^{3}$ Mushroom Research Division, National Institute of Horticultural and Herbal Science, Rural Development Administration, \\ Eumseong 369-873, Republic of Korea \\ ${ }^{4}$ Forest Biodiversity Division, Korea National Arboretum, Pocheon 487-820, Republic of Korea \\ ${ }^{5}$ College of Pharmacy, Chung-Ang University, Seoul 156-756, Republic of Korea
}

Correspondence should be addressed to Gi-Ho Sung; sung97330@gmail.com

Received 13 December 2015; Accepted 19 January 2016

Academic Editor: Dagmar Triebel

Copyright (C) 2016 Bhushan Shrestha et al. This is an open access article distributed under the Creative Commons Attribution License, which permits unrestricted use, distribution, and reproduction in any medium, provided the original work is properly cited.

Entomophthoralean and ascomycetous fungi are the two major groups known to parasitize arthropods in almost every terrestrial habitat of the earth. Within Ascomycota, Cordyceps sensu lato is a large genus with more than 400 spp. described on numerous orders of Arthropoda. Among the hosts of Cordyceps, Coleoptera and Lepidoptera are the two major orders. Out of the estimated 200 Cordyceps spp. recorded on coleopteran and lepidopteran hosts, we have documented $92 \mathrm{spp}$. based on the available information of their host species. Among coleopteran hosts, Scarabaeidae and Elateridae are the two major families. Similarly, among lepidopterans, Hepialidae is the largest host family. Cordyceps militaris shows the widest host range, extending to 2 orders, 13 families, and $32 \mathrm{spp}$. We hope such accumulative work will be useful as a quick reference for interested biologists, forest ecologists, biocontrol researchers, and fungal and insect taxonomists to apprehend host range and host specificities of Cordyceps fungi.

\section{Introduction}

Fungi play vital roles in the recycling of organic matter in the terrestrial habitat of the earth. Besides that, they also parasitize living organisms and cause various diseases on plants, animals, and insects. Estimates show 750-1000 fungal spp. parasitizing insects naturally $[1,2]$, although the extent of the diversity of the entomopathogenic fungi is not completely known $[3,4]$. The entomopathogenic fungi mainly belong to two diverse groups within kingdom Fungi, Entomophthorales (Phylum Entomophthoromyota, formerly Zygomycota) and Hypocreales (Phylum Ascomycota). These fungi are distributed in wide terrestrial ecosystems of the world including Arctic Circle and Antarctica [5]. Entomophthoralean pathogens generally show narrow host range and are distributed in temperate forests [6] with rare reports from tropical regions [7]. Hypocrealean pathogens, on the other hand, have narrow to very broad host range [4] and are dominantly distributed in humid tropical forests [7].

Cordyceps Fr. is one of the hypocrealean genera, comprising more than $400 \mathrm{spp}$. that parasitize a wide range of insects and few fungal genera. Externally, they produce clavate, cylindrical or thin filamentous, filiform stroma on the hosts. The history of exploring and identifying Cordyceps fungi is long and stretches back to the 17th century [8]. One of the most popular fungi is Ophiocordyceps sinensis (syn. Cordyceps sinensis) that grows on hepialid larvae in the alpine grasslands of the Himalayas and the Tibetan Plateau [9]. This host-fungus complex is traditionally highly revered for enhancing immunity, protecting lungs, enriching kidneys, restorative and tonic effects, treating impotence, and so forth [10-13]. 
Until the phylogenetic classification by Sung et al. [14], Cordyceps remained a big genus placed in family Clavicipitaceae of order Hypocreales. However, phylogenetic studies showed that neither Cordyceps nor Clavicipitaceae was monophyletic [14-18] and hence Cordyceps was segregated into several phylogenetic genera within three families of Hypocreales [14]. According to the phylogenetic classification, Cordyceps is now restricted to the clade containing the type species C. militaris, circumscribed to Cordycipitaceae [14]. Newly segregated genera Ophiocordyceps and Elaphocordyceps were placed under another family Ophiocordycipitaceae; the other two genera Metacordyceps and Tyrannicordyceps remained in Clavicipitaceae sensu stricto $[14,19]$.

Following the recent revision in the International Code of Nomenclature for algae, fungi, and plants (ICN), Elaphocordyceps is now synonymized with Tolypocladium [20] and Metacordyceps with Metarhizium [21]. Drechmeria, Podocrella, Polycephalomyces, and Sphaerocordyceps are other genera that consist of members that were formerly described under Cordyceps. Cordyceps along with the newly segregated genera is linked to many asexual insect-pathogenic genera distributed in all three families Clavicipitaceae s. s., Cordycipitaceae, and Ophiocordycipitaceae [4, 14, 20]. Further synonymizations of genera are recently proposed within Ophiocordycipitaceae following ICN [22].

The host range of Cordyceps in classical sense is very broad and includes several orders (Coleoptera, Lepidoptera, Hymenoptera, Hemiptera, Orthoptera, Araneae, Diptera, Blattodea, Mantodea, Dermaptera, Odonata, Phasmatodea, etc.). Based on the published literature, nearly $60 \%$ of the species of Cordyceps sensu lato are recorded on two orders Coleoptera and Lepidoptera. The other major host orders are Hymenoptera, Hemiptera, Orthoptera, and Araneae. The majority of hosts (more than 95\%) in Lepidoptera (moths, butterflies) and Coleoptera (beetle) are larvae; the rest are adults or pupae, making the host identification difficult. In contrast, majority of hosts in other orders are adults such as spiders (Araneae), fly (Diptera), ant, bee, and wasp (Hymenoptera), grasshopper, locust, and cricket (Orthoptera), cicada, bug, scale-insect, and coccid (Hemiptera), cockroach and termite (Blattodea), mantis (Mantodea), earwig (Dermaptera), dragonfly (Odonata), and stick-insect (Phasmatodea). Why lepidopterans and coleopterans are mostly susceptible at larval stage while other orders are more susceptible at adult stage is not well understood.

\section{Host-Pathogen Interaction}

Cordyceps fungi range in habitat from aerial to epigeal to subterranean ones [74], based on their respective host species. When the host stage is adult, they grow on exposed environments such as leaf litter or are attached to some plant parts such as leaf and branch and in contrast to the larval or pupal stages that are buried in soil (hypogeal) or on wood up to nearly $50 \mathrm{~cm}$, for example, O. longissima [75] and $O$. xuefengensis [76]. Ophiocordyceps caloceroides that is buried in the soil more than $50 \mathrm{~cm}$ is exceptional which grows on adult spiders [77].
The pathogenic fungi sometimes produce parasite manipulated behaviors on hosts, such as death grip or biting behavior [78-80]. Some of the parasitized ants always bite lower side veins but never the laminar blade or the upper surface $[79,80]$. Similarly, some species of ants are attached to lower side of twigs whereas others are found attached to leaves [81]. In other cases, aphids, ants, grasshoppers, planthoppers, flies, and so forth shift to elevated position at the time of dying, known as summit disease [82, 83].

In this review, we present brief introductions of Coleoptera and Lepidoptera and their major subgroups parasitized by Cordyceps fungi. We hope the present review will serve as a reference for researchers and scholars to get a quick look at coleopteran and lepidopteran hosts of Cordyceps spp.

\section{Materials and Methods}

We accumulated host information from published literature and analysed the hosts that belonged to Coleoptera and Lepidoptera. We found that hosts of only $60 \%$ of Cordyceps fungi are known at family or genus/species ranks; the rest are known only at the order rank and hence no further discussions of the hosts could be done for them. Hence, in this review, we dealt with only those hosts that are known at family or infrafamily ranks within Coleoptera and Lepidoptera and tried to analyse the major taxonomic subgroups that are associated with Cordyceps fungi. We also analysed the host stage among coleopteran and lepidopteran hosts based on published literature.

\section{Coleopteran Hosts}

Coleoptera is currently the most species-rich group on this planet [84]. The order is classified into four suborders (Polyphaga, Adephaga, Myxophaga, and Archostemata) [85]. Polyphaga is the largest suborder covering $90 \%$ of total beetle species and is classified into more than 170 families. Adephaga is the second largest suborder, followed by Myxophaga and Archostemata. All the known coleopteran hosts belong to suborders Polyphaga and Adephaga under 8 superfamilies and 11 families. Short descriptions of host families are given below, followed by Cordyceps spp. recorded on them.

\subsection{Superfamily Scarabaeoidea}

4.1.1. Scarabaeidae. This is one of the largest families in Coleoptera and its members are commonly called scarabs or scarab beetles. Scarabaeid larvae (commonly called grubs) are short, thick, pale yellow or white, mostly live underground or under debris, and feed on dead organic matter (scavengers). Twenty-seven Cordyceps spp. are recorded in this family (Table 1). Among them, C. brittlebankii is recorded on Heteronyx sp., C. brongniartii on Anomala cuprea, C. coxii on Lepidiota sp., C. pseudoinsignis and C. velutipes on Melolontha sp., Ophiocordyceps aphodii on Aphodius howitti and A. tasmaniae, O. melolonthae on Ancyloncha puncticollis, Lachnosterna fusca, and Melolontha sp., O. michiganensis on Scarabaeus sp., O. ravenelii on L. fusca, Phyllophaga 
TABLE 1: An aggregate list of coleopteran hosts (family/genus/species) of Cordyceps species.

\begin{tabular}{|c|c|c|c|c|}
\hline S number & Cordyceps sp. & Family & Genus/species & Host stage \\
\hline 1 & C. aurantiaca & Elateridae & - & Larva [23] \\
\hline 2 & C. brittlebankii & Scarabaeidae & Heteronyx sp. & Larva [24] \\
\hline 3 & C. brongniartii & Scarabaeidae & Anomala cuprea & Larva [25] \\
\hline 4 & C. coxii & Scarabaeidae & Lepidiota sp. & Larva [26] \\
\hline 5 & C. erotyli & Erotylidae & Erotylus sp. & Adult [27] \\
\hline 6 & C. geotrupis & Geotrupidae & Geotrupes sp. & Adult [28] \\
\hline 7 & C. huntii & Elateridae & - & Larva [29] \\
\hline 8 & C. memorabilis & Staphylinidae & Staphylinus sp. & Adult [30] \\
\hline 9 & C. militaris & $\begin{array}{l}\text { Curculionidae } \\
\text { Tenebrionidae }\end{array}$ & $\begin{array}{l}\text { Ips sexdentatus } \\
\text { Tenebrio molitor }\end{array}$ & Larva $[31,32]$ \\
\hline 10 & C. nikkoensis & Carabidae & - & Larva [33] \\
\hline 11 & C. nirtolii & Elateridae & Melanotus communis & Larva [34] \\
\hline 12 & C. obliquiordinata & Scarabaeidae & - & Larva [35] \\
\hline 13 & C. pseudoinsignis & Scarabaeidae & Melolontha sp. & Larva [36] \\
\hline 14 & C. rubra & Elateridae & - & Larva [37] \\
\hline 15 & C. scarabaeicola & Scarabaeidae & - & Adult [38] \\
\hline 16 & C. shanxiensis & Elateridae & Melanotus caudex, Pleonomus canaliculatus & Larva [39] \\
\hline 17 & C. staphylinidicola & Staphylinidae & - & Larva $[40]$ \\
\hline 18 & C. velutipes & $\begin{array}{c}\text { Elateridae } \\
\text { Scarabaeidae }\end{array}$ & Melolontha sp. & Larva $[36,41]$ \\
\hline 19 & M. brittlebankisoides & Scarabaeidae & - & Larva $[42]$ \\
\hline 20 & M. campsosterni & Elateridae & Campsosternus auratus & Larva $[43]$ \\
\hline 21 & M. martiale & Elateridae & Hemirhipus sp. & Larva [44] \\
\hline 22 & O. acicularis & Tenebrionidae & Nictobates sp. & Larva $[41]$ \\
\hline 23 & O. aphodii & Scarabaeidae & Aphodius howitti, A. tasmaniae & Larva $[45,46]$ \\
\hline 24 & O. arbuscula & Scarabaeidae & - & Larva [47] \\
\hline 25 & O. barnesii & Scarabaeidae & - & Larva [41] \\
\hline 26 & O. brunneipunctata & Elateridae & - & Larva $[48]$ \\
\hline 27 & O. carabidicola & Carabidae & - & Larva [49] \\
\hline 28 & O. curculionum & Curculionidae & Heilipus celsus & Adult [41] \\
\hline 29 & O. dovei & Cerambycidae & Oemona hirta & Larva $[50]$ \\
\hline 30 & O. elateridicola & Elateridae & - & Larva [33] \\
\hline 31 & $\begin{array}{c}\text { O. } \\
\text { elongatiperitheciata }\end{array}$ & Scarabaeidae & - & Larva [51] \\
\hline 32 & O. entomorrhiza & $\begin{array}{l}\text { Cerambycidae } \\
\text { Chrysomelidae } \\
\text { Curculionidae } \\
\text { Staphylinidae } \\
\text { Tenebrionidae }\end{array}$ & $\begin{array}{c}\text { Calathus sp., Calosoma sp., Carabus } \\
\text { auronitens, C. coriaceus, C. glabratus, C. } \\
\text { hortensis, C. intricatus, C. nemoralis, C. } \\
\text { nemorensis, C. violaceus, Coptolabrus sp., } \\
\text { Hadrocarabus problematicus, Pterostichus sp. } \\
\text { Leptura sp. } \\
\text { Diabrotica sp. } \\
\text { Apion flavipes } \\
\text { Ocypus sp. } \\
\text { Meneristes laticollis }\end{array}$ & $\begin{array}{c}\text { Larva, adult } \\
{[41,50,52-57]}\end{array}$ \\
\hline 33 & O. formosana & Tenebrionidae & - & Larva $[58]$ \\
\hline 34 & O. geniculata & Scarabaeidae & - & Larva [59] \\
\hline 35 & O. gracilioides & Elateridae & - & Larva [59] \\
\hline 36 & O. gracillima & Scarabaeidae & - & Larva $[60]$ \\
\hline
\end{tabular}


TABle 1: Continued.

\begin{tabular}{|c|c|c|c|c|}
\hline S number & Cordyceps sp. & Family & Genus/species & Host stage \\
\hline 37 & O. highlandensis & Scarabaeidae & - & Larva $[61]$ \\
\hline 38 & O. jiangxiensis & Elateridae & Campsosternus auratus, C. fruhstorferi & Larva [62] \\
\hline 39 & O. konnoana & Scarabaeidae & - & Larva [59] \\
\hline 40 & O. larvicola & $\begin{array}{l}\text { Cerambycidae } \\
\text { Scarabaeidae } \\
\text { Tenebrionidae }\end{array}$ & $\begin{array}{c}\text { Callidium sp. } \\
- \\
\text { Cylindronotus sp., Helops caraboides, } H . \\
\text { lanipes }\end{array}$ & $\begin{array}{l}\text { Larva } \\
{[36,50,63]}\end{array}$ \\
\hline 41 & O. macularis & Scarabaeidae & - & Larva [64] \\
\hline 42 & O. melolonthae & Scarabaeidae & $\begin{array}{c}\text { Ancyloncha puncticollis, Lachnosterna fusca, } \\
\text { Melolontha sp. }\end{array}$ & Larva $[41,65]$ \\
\hline 43 & O. michiganensis & $\begin{array}{l}\text { Carabidae } \\
\text { Scarabaeidae }\end{array}$ & Scarabaeus sp. & Larva $[50,66]$ \\
\hline 44 & O. neovolkiana & Scarabaeidae & - & Larva $[50]$ \\
\hline 45 & O. nigrella & Scarabaeidae & - & Larva [33] \\
\hline 46 & O. purpureostromata & Elateridae & - & Larva $[51]$ \\
\hline 47 & O. ravenelii & Scarabaeidae & $\begin{array}{c}\text { Lachnosterna fusca, Phyllophaga sp., } \\
\text { Rhizotrogus sp. }\end{array}$ & $\begin{array}{c}\text { Larva } \\
{[65,67,68]}\end{array}$ \\
\hline 48 & O. salebrosa & Elateridae & - & Adult [69] \\
\hline 49 & O. scottiana & Lucanidae & Rhyssonotus nebulosus & Larva [26] \\
\hline 50 & O. stylophora & $\begin{array}{l}\text { Carabidae } \\
\text { Cerambycidae } \\
\text { Elateridae } \\
\text { Scarabaeidae }\end{array}$ & $\begin{array}{c}- \\
\text { Phoracantha semipunctata } \\
\text { Denticollis linearis } \\
\text { Costelytra zealandica }\end{array}$ & $\begin{array}{l}\text { Larva } \\
{[52,70-72]}\end{array}$ \\
\hline 51 & O. superficialis & $\begin{array}{l}\text { Chrysomelidae } \\
\text { Staphylinidae } \\
\text { Scarabaeidae }\end{array}$ & $\begin{array}{l}- \\
- \\
-\end{array}$ & $\begin{array}{c}\text { Larva } \\
{[27,49,73]}\end{array}$ \\
\hline 52 & O. variabilis & Scarabaeidae & - & Larva $[73]$ \\
\hline 53 & O. volkiana & Carabidae & Eripus heterogaster & Larva [37] \\
\hline 54 & P. peltata & Curculionidae & Cryptorhynchus corticicolus & Larva $[68]$ \\
\hline 55 & S. palustris & Scarabaeidae & - & Larva [37] \\
\hline
\end{tabular}

sp., and Rhizotrogus sp., and O. stylophora on Costelytra zealandica (Table 1). Other species recorded in this family are C. obliquiordinata, C. scarabaeicola, Metarhizium brittlebankisoides, Ophiocordyceps arbuscula, O. barnesii, O. elongatiperitheciata, O. geniculata, O. gracillima, O. highlandensis, O. konnoana, O. larvicola, O. macularis, O. neovolkiana, O. nigrella, O. superficialis, O. variabilis, and Sphaerocordyceps palustris (Table 1). Out of 27 Cordyceps spp., 26 are recorded on larvae except $C$. scarabaeicola that is recorded on adult (Table 1).

4.1.2. Geotrupidae. Members of this family are commonly called earth-boring dung beetles, which mostly excavate burrows to lay their eggs. They are normally detritivores but occasionally behave as coprophagous. Cordyceps geotrupis is recorded on an adult of Geotrupes sp. in this family (Table 1).

4.1.3. Lucanidae. Members of this family are commonly called stag beetles. The name stag beetle is derived from the distinctive mandibles found on the males that resemble the antlers of stags. The larvae feed on rotting deciduous wood for several years before pupating. Ophiocordyceps scottiana is recorded on Rhyssonotus nebulosus in this family (Table 1).

\subsection{Superfamily Elateroidea}

4.2.1. Elateridae. Members of this family are commonly called click beetles, elaters, snapping beetles, spring beetles, skipjacks, and so forth. The adults are typically nocturnal and phytophagous. Larvae are slender, elongate, cylindrical, or somewhat flattened, with relatively hard bodies, somewhat resembling mealworms. Fifteen spp. of Cordyceps have been recorded from this family (Table 1), all of which grow on larvae except Ophiocordyceps salebrosa that grows on an adult (Table 1). Six spp. are recorded on larvae of the following hosts: Cordyceps nirtolii on Melanotus communis, C. shanxiensis on M. caudex and Pleonomus canaliculatus, Metarhizium campsosterni on Campsosternus auratus, $M$. martiale on Hemirhipus sp., Ophiocordyceps jiangxiensis on $C$. auratus and C. fruhstorferi, and O. stylophora on Denticollis linearis (Table 1). Other spp. recorded in this family are Cordyceps aurantiaca, C. huntii, C. rubra, C. velutipes, Ophiocordyceps brunneipunctata, O. elateridicola, O. gracilioides, $O$. purpureostromata, and O. salebrosa (Table 1).

\subsection{Superfamily Chrysomeloidea}

4.3.1. Cerambycidae. The long-horned beetles, also known as longicorns, are cosmopolitan, typically characterized by 
extremely long antennae, which are often as long as or longer than the beetle's body. The larvae, called roundheaded borers, bore into wood, where they can cause extensive damage to either living trees or untreated lumber. Four spp. are known from this family, all growing on larvae (Table 1). They are Ophiocordyceps dovei on Oemona hirta, O. entomorrhiza on Leptura sp., O. larvicola on Callidium sp., and O. stylophora on Phoracantha semipunctata.

4.3.2. Chrysomelidae. The family, commonly known as leaf beetle, is one of the largest beetle families. Adults and larvae feed on all sorts of plant tissues. Most chrysomelids are conspicuously colored, typically in glossy yellow to red or metallic blue-green hues. Ophiocordyceps entomorrhiza is recorded on adult of Diabrotica sp. and O. superficialis on a chrysomelid larva (Table 1).

\subsection{Superfamily Cucujoidea}

4.4.1. Erotylidae. It is a family of the pleasing fungus beetles. They feed on plant and fungal matter, a few of them being notable pests. Cordyceps erotyli is recorded on adult of Erotylus sp. in this family (Table 1).

\subsection{Superfamily Curculionoidea}

4.5.1. Curculionidae. It is the family of the true weevils or snout beetles. Weevils are almost entirely plant feeders. Cordyceps militaris is recorded on larva of Ips sexdentatus, Ophiocordyceps curculionum on adult of Heilipus celsus, O. entomorrhiza on adult of Apion flavipes, and Podocrella peltata on larva of Cryptorhynchus corticicolus (Table 1).

\subsection{Superfamily Tenebrionoidea}

4.6.1. Tenebrionidae. Tenebrionids are often referred to as darkling beetles as they have usually black or brown elytra and are nocturnal in habit. They are found worldwide though they are more diverse in semiarid and arid ecosystems. Adults of most species are saprophagous while larvae are mostly detritivores (litter feeders) or xylophagous. Five spp. are recorded on larvae of this family (Table 1): C. militaris on Tenebrio molitor, $O$. acicularis on Nictobates sp., $O$. entomorrhiza on Meneristes laticollis, and O. larvicola on Cylindronotus sp., Helops caraboides, and H. lanipes. Ophiocordyceps formosana is the fifth species recorded on larva of this family.

\subsection{Superfamily Staphylinoidea}

4.7.1. Staphylinidae. The rove beetles belong to family Staphylinidae, primarily distinguished by their short elytra. The group is currently recognized as the largest family of beetles. They are an ecologically and morphologically diverse group of beetles and commonly encountered in terrestrial ecosystems. Cordyceps memorabilis is recorded on adult of Staphylinus sp. whereas Ophiocordyceps entomorrhiza is recorded on larva of Ocypus sp. Cordyceps staphylinidicola and O. superficialis are other spp. recorded on larvae of this family (Table 1).

\subsection{Superfamily Caraboidea}

4.8.1. Carabidae. It is a large, cosmopolitan family. Its members are commonly known as ground beetles. They are mostly shiny black or metallic and have ridged wing covers (elytra). Common habitats are under the bark of trees, under logs, or among rocks or sand by the edge of ponds and rivers. Six spp. are known from this family (Table 1). Among them, O. entomorrhiza is recorded on adults and larvae of several species such as Carabus auronitens, C. coriaceus, C. glabratus, C. hortensis, C. intricatus, C. nemoralis, C. nemorensis, C. violaceus, Calathus sp., Calosoma sp., Coptolabrus sp., Hadrocarabus problematicus, and Pterostichus sp. Ophiocordyceps volkiana is recorded on larva of Eripus heterogaster. Cordyceps nikkoensis, Ophiocordyceps carabidicola, O. michiganensis, and $O$. stylophora are other species recorded on larvae of this family.

Among the coleopteran families, Scarabaeidae is parasitized by the highest number of Cordyceps fungi (27 spp.), followed by Elateridae (15 spp.) (Table 1). Among 55 parasitizing fungi (Table 1), we found that only few parasitize more than one family. For example, Ophiocordyceps entomorrhiza parasitizes 6 families, followed by O. stylophora (4 families), $O$. larvicola and O. superficialis (3 families each), and C. militaris, C. velutipes, and O. michiganensis (2 families each) (Table 1). From host range point of view, Ophiocordyceps entomorrhiza shows the widest range, infecting 13 spp. in Carabidae and one sp. in each Cerambycidae, Chrysomelidae, Curculionidae, Staphylinidae, and Tenebrionidae (Table 1). It is also exceptional in that it infects both larval and adult stages.

As mentioned earlier, larva is the most dominant host stage susceptible to Cordyceps pathogens in Coleoptera, with fewer adult stages being parasitized (Table 1). Besides $O$. entomorrhiza, six other spp. are recorded on coleopteran adults. They are C. erotyli, C. geotrupis, C. memorabilis, $O$. curculionum, O. salebrosa, and C. scarabaeicola; the remaining ones are recorded on larvae.

\section{Lepidopteran Hosts}

Lepidoptera is among the large orders of insects [121]. It has around 160,000 spp. that are classified into 4 suborders, 45 superfamilies, and 139 families [122]. Out of four suborders (Aglossata, Glossata, Heterobathmiina, and Zeugloptera), Cordyceps and allied genera are known only from Glossata. It is the largest suborder consisting of almost $99.9 \%$ of all described lepidopterans $[122,123]$. It is further classified into six infraorders (Dacnonypha, Acanthoctesia, Lophocoronina, Neopseustina, Exoporia, and Heteroneura) [122]. Among them, Cordyceps hosts are known from two infraorders Exoporia and Heteroneura.

Lepidopterans have from three to more than a dozen larval instars (caterpillars), often five [123, 124], inhabiting as root- or stem-borers or foliage eaters and leaf-miners of angiosperms, usually within narrow range of host plants. Lepidopterans have distinct feeding habits, basically plantfeeding during larval stage and nectar-feeding during adult stage. Exoporia and Heteroneura are discussed below in short, followed by Cordyceps pathogens parasitizing them. 
TABLE 2: Cordyceps species recorded on hepialid hosts (Lepidoptera, Glossata, Exoporia, and Hepialidae).

\begin{tabular}{|c|c|c|c|}
\hline S number & Cordyceps species & Genus/species & Host stage \\
\hline 1 & C. cranstounii & Oxycanus dirempta, Abantiades sp. & Larva $[86]$ \\
\hline 2 & C. cuncunae & - & Larva [87] \\
\hline 3 & C. hawkesii & Oxycanus sp., Trictena sp., Abantiades sp. & Larva $[26,86]$ \\
\hline 4 & C. hepialidicola & Endoclita excrescens & Larva $[88]$ \\
\hline 5 & C. kurijimeansis & Thitarodes armoricanus & Larva [34] \\
\hline 6 & C. militaris & Hepialus sp. & $\begin{array}{l}\text { Larva, pupa } \\
\quad[89]\end{array}$ \\
\hline 7 & D. gunnii & $\begin{array}{l}\text { Abantiades labyrinthicus, Aoraia enysii, Oxycanus sp., } \\
\text { Trictena atripalpis }\end{array}$ & $\begin{array}{l}\text { Larva, pupa } \\
{[26,46,86]}\end{array}$ \\
\hline 8 & O. crassispora & Thitarodes baimaensis & Larva $[90]$ \\
\hline 9 & O. emeiensis & - & Larva $[91]$ \\
\hline 10 & O. gracilis & $\begin{array}{l}\text { Ahamus altaicola, Hepialus humuli, Korscheltellus } \\
\text { lupulina, Parahepialus nebulosus }\end{array}$ & Larva $[57,92]$ \\
\hline 11 & O. robertsii & $\begin{array}{l}\text { Aenetus virescens, Aoraia dinodes, A. ensyii, Dasypodia } \\
\text { selenophora, Wiseana spp. }\end{array}$ & $\begin{array}{l}\text { Larva } \\
{[46,93,94]}\end{array}$ \\
\hline 12 & O. sinensis & $\begin{array}{l}\text { Ahamus anomopterus, A. gangcaensis, A. } \\
\text { jianchuanensis, A. lijiangensis, A. luquensis, A. } \\
\text { maquensis, A. sichuanus, A. yulongensis, A. } \\
\text { yunlongensis, A. yunnanensis, A. yushuensis, A. } \\
\text { zadoiensis, A. zhayuensis, Bipectilus yunnanensis, } \\
\text { Endoclita davidi, Gazoryctra ganna, } \\
\text { Hepialus xiaojinensis, Magnificus jiuzhiensis, M. } \\
\text { zhiduoensis, Parahepialus nebulosus, Pharmacis carna, } \\
\text { P. fusconebulosa, P. pyrenaicus, Thitarodes albipictus, T. } \\
\text { armoricanus, T. baimaensis, T. baqingensis, T. bibelteus, } \\
\text { T. biruensis, T. callinivalis, T. cingulatus, T. } \\
\text { damxungensis, T. deqinensis, T. dongyuensis, T. } \\
\text { ferrugineus, T. gonggaensis, T. jialangensis, T. } \\
\text { jinshaensis, T. kangdingensis, T. kangdingroides, T. } \\
\text { latitegumenus, T. litangensis, T. markamensis, T. } \\
\text { meiliensis, T. namensis, T. namlinensis, T. oblifurcus, T. } \\
\text { pratensis, T. pui, T. renzhiensis, T. varians, T. } \\
\text { xunhuaensis, T. yeriensis, T. zaliensis, T. zhongzhiensis }\end{array}$ & Larva $[95,96]$ \\
\hline 13 & O. taylorii & Trictena sp. & Pupa [86] \\
\hline 14 & O. lanpingensis & Ahamus jianchuanensis, A. yunnanensis & Larva [97] \\
\hline 15 & O. laojunshanensis & Ahamus yunnanensis & Larva $[98]$ \\
\hline 16 & O. ramosissimum & Endoclita nodus & Larva [99] \\
\hline 17 & O. xuefengensis & Endoclita nodus & Larva [76] \\
\hline
\end{tabular}

5.1. Infraorder Exoporia. It is a small infraorder consisting of $636 \mathrm{spp}$. that are classified into 2 superfamilies [122]. Cordyceps and allied genera are recorded only from the superfamily Hepialoidea. The superfamily comprises five families that are distributed in diverse vegetation such as forest, shrubland, grassland, tundra, swamp, and bog with the most varied diet habit among moth families [123, 125]. Among the families, Cordyceps spp. are recorded from family Hepialidae alone (Table 2).

Ophiocordyceps sinensis has the widest host range recorded on Hepialidae, covering 55 spp. [95, 96]. Among them, Thitarodes and Ahamus are the two major genera (Table 2). Thirty-two spp. of Thitarodes (T. albipictus, $T$. armoricanus, T. baimaensis, T. baqingensis, T. bibelteus, $T$. biruensis, T. callinivalis, T. cingulatus, T. damxungensis, T. deqinensis, T. dongyuensis, T. ferrugineus, T. gonggaensis, T. jialangensis, T. jinshaensis, T. kangdingensis, T. kangdingroides, T. latitegumenus, T. litangensis, T. markamensis, T. meiliensis, T. namensis, T. namlinensis, T. oblifurcus, T. pratensis, T. pui, T. renzhiensis, T. varians, T. xunhuaensis, T. yeriensis, T. zaliensis, and T. zhongzhiensis) and 13 spp. of Ahamus (A. anomopterus, A. gangcaensis, A. jianchuanensis, A. lijiangensis, A. luquensis, A. maquensis, A. sichuanus, $A$. yulongensis, A. yunlongensis, A. yunnanensis, A. yushuensis, A. zadoiensis, and A. zhayuensis) are the host species of Ophiocordyceps sinensis (Table 2). The other host species are Pharmacis carna, P. fusconebulosa, P. pyrenaicus, Magnificus jiuzhiensis, M. zhiduoensis, Bipectilus yunnanensis, Endoclita davidi, Gazoryctra ganna, Parahepialus nebulosus, and Hepialus xiaojinensis (Table 2). 
There are other species that share similar hosts as Ophiocordyceps sinensis. For example, O. crassispora and C. kurijimeansis are recorded on Thitarodes baimaensis and T. armoricanus, respectively (Table 2). Ophiocordyceps gracilis, $O$. lanpingensis, and $O$. laojunshanensis are recorded on Ahamus altaicola, A. jianchuanensis, and A. yunnanensis, respectively (Table 2). Ophiocordyceps gracilis is also recorded on three more hosts Hepialus humuli, Korscheltellus lupulina, and Parahepialus nebulosus. Similarly, Cordyceps hepialidicola is reported on Endoclita excrescens and O. ramosissimum and O. xuefengensis on Endoclita nodus (Table 2).

Many species are recorded in Australia and New Zealand on hepialid hosts. For instance, Cordyceps cranstounii, C. hawkesii, D. gunnii, O. robertsii, and O. taylorii are recorded on Abantiades labyrinthicus and other Abantiades spp., Aenetus virescens, Aoraia dinodes, A. ensyii, Dasypodia selenophora, Oxycanus dirempta, and other Oxycanus spp., Trictena atripalpis and other Trictena spp., Wiseana spp., and so forth (Table 2). Another Cordyceps sp. rarely described on Hepialus is C. militaris (Table 2). Besides that, Cordyceps cuncunae and O. emeiensis are also recorded on hepialid hosts (Table 2).

5.2. Infraorder Heteroneura. This infraorder consists of more than $98 \%$ of lepidopteran species [122]. Nine superfamilies among more than 30 in the infraorder are recorded as hosts of Cordyceps spp. Among the host families, Tineidae is the only microlepidopteran family; the rest are macrolepidopterans. Papilionidae and Pieridae are the two butterfly families, the rest being moths. The host families are briefly described below followed by Cordyceps spp. recorded on them.

\subsubsection{Superfamily Noctuoidea}

(1) Erebidae. It is the largest family in Lepidoptera with 24,569 described spp. [122]. Despite the high species richness, only two Cordyceps spp. are recorded on this family. Of them, $C$. militaris is recorded on Calliteara pudibunda and Leucoma salicis whereas $C$. nikkoensis is reported on a larva of the family (Table 3).

(2) Noctuidae. It is commonly known as owlet moths. Cordyceps militaris is recorded on 4 spp. of this family: Arcte coerula, Colocasia coryli, Euxoa ochrogaster, and Panolis flammea (Table 3). Ophiocordyceps elongata is recorded on Acronicta americana. Other species recorded in this family are Cordyceps alpicola, C. bifusispora, C. bulolensis, C. cristata, and C. tuberculata (Table 3).

(3) Notodontidae. Its members are mainly concentrated in the tropical areas. Some examples of this family are puss moths. Cordyceps militaris is recorded on $5 \mathrm{spp}$. of this family. They are Fentonia ocypete, Lampronadata cristata, Phalera assimilis, P. bucephala, and Syntypistis punctatella (Table 3).

\subsubsection{Superfamily Zygaenoidea}

(1) Limacodidae (Cochlididae). The members of this family are known as slug moths and are mostly tropical. Ophiocordyceps cochlidiicola is recorded on larva and pupa of this family (Table 3).

\subsubsection{Superfamily Cossoidea}

(1) Cossidae. The members are known as carpenter millers and are found worldwide. Four spp. are recorded in this family. Of them, Metarhizium indigoticum is recorded on Yakudza vicarius. Two recently described spp., Ophiocordyceps arborescens and $O$. macroacicularis, are recorded on Cossus sp. (Table 3). The other species recorded on this family is Cordyceps bassiana.

\subsubsection{Superfamily Drepanoidea}

(1) Drepanidae. The members of this family have worldwide distribution. Cordyceps militaris is recorded on 4 spp. of this family: Achlya flavicornis, Ochropacha duplaris, Tethea ocularis, and Tetheella fluctuosa (Table 3).

\subsubsection{Superfamily Tineoidea}

(1) Tineidae. The members are small to medium-sized moths. They are worldwide in distribution but are particularly common in the Palaeartic ecozone. Cordyceps cardinalis is recorded on larva of this family (Table 3 ).

\subsubsection{Superfamily Papilionoidea}

(1) Papilionidae. It is a family of colorful swallowtail butterflies. Some of the members are the largest butterflies in the world. The majority are distributed in the tropical region. Cordyceps tuberculata is reported on adult of this family (Table 3).

(2) Pieridae. It is a large family of butterfly, mostly distributed in the tropical parts of the world. Its members are mostly white, orange, or yellow in pigmentation. Metarhizium taii is reported on Pieris rapae in this family (Table 3).

\subsubsection{Superfamily Geometroidea}

(1) Geometridae. It is the second largest family in Lepidoptera with 23,002 spp. [122]. It is commonly known as inch worms. Some of the members are notorious pests. Cordyceps militaris and $C$. riverae are recorded from this family parasitizing Biston panterinaria, Lycia hirtaria, and Triphosa sp. (Table 3).

\subsubsection{Superfamily Bombycoidea}

(1) Bombycidae. It is known as silkworm family. The most well-known member is Bombyx mori, native to northern China. Cordyceps militaris is recorded on B. mori and C. michaelisii on a species of Bombyx (Table 3).

(2) Endromidae. This is a small family. Cordyceps militaris is recorded on Andraca bipunctata in this family (Table 3).

(3) Saturniidae. The members include giant silk moths, royal moths, and emperor moths. They are described worldwide 


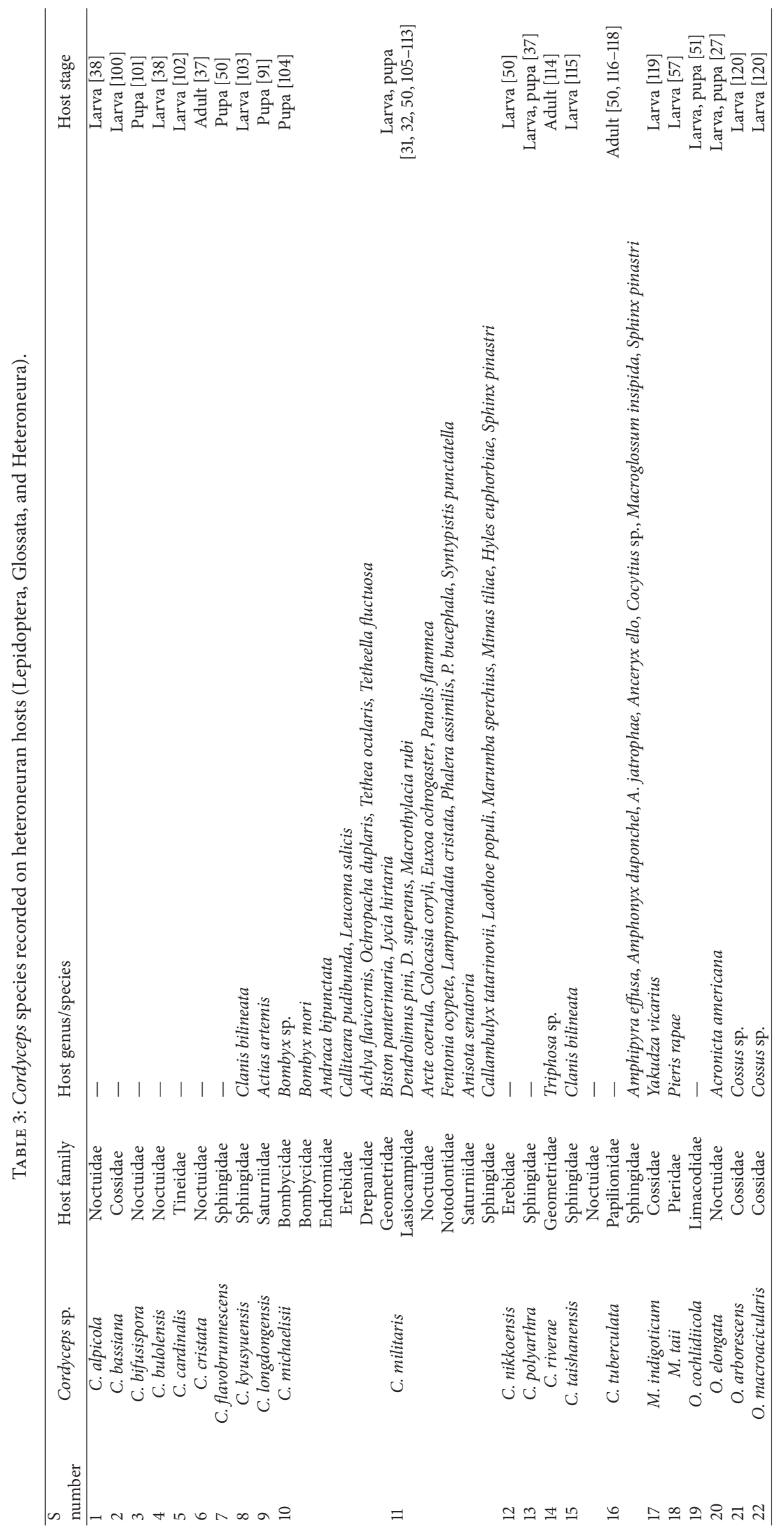


but are particularly known from tropical and subtropical regions. Some of the members are the largest moth species. Cordyceps longdongensis parasitizes Actias artemis whereas $C$. militaris parasitizes Anisota senatoria (Table 3).

(4) Sphingidae. The members of this family are commonly known as hawk moths or sphinx moths. They are moderate to large in size and are mainly described from the tropical parts. Cordyceps militaris is recorded on various species in this family such as Callambulyx tatarinovii, Laothoe populi, Marumba sperchius, Mimas tiliae, Hyles euphorbiae, and Sphinx pinastri and C. tuberculata on Amphipyra effusa, Amphonyx duponchel, A. jatrophae, Anceryx ello, Cocytius sp., Macroglossum insipida, and S. pinastri. Two other spp. Cordyceps kyusyuensis and C. taishanensis are recorded on Clanis bilineata. Cordyceps flavobrunnescens and C. polyarthra are other spp. recorded from this family.

\subsubsection{Superfamily Lasiocampoidea}

(1) Lasiocampidae. Its members are known as snout moths or lappet moths. They are large in size with broad wings and are known worldwide. Cordyceps militaris is reported on Dendrolimus pini, D. superans, and Macrothylacia rubi (Table 3).

Out of 22 spp. recorded on heteroneuran hosts (Table 3), C. militaris has the widest host range, extending to 2 infraorders, 6 superfamilies, 10 families, and 29 spp. (Table 3 ). It is a cosmopolitan species, distributed from sea level to more than $2000 \mathrm{~m}$ above sea level [126]. Probably due to its wide host range and adaptability to wider habitats, this species demonstrates rapid in vitro growth and fructifications [127]. Cordyceps tuberculata is another species recorded on multiple families. Larva is the most suitable host for Cordyceps spp. compared to pupa and adult (Table 3).

In total, 16 families in Lepidoptera (1 exoporian and 15 heteroneuran) are identified as host families of Cordyceps and allied genera. Hepialidae, though a small family, hosts 6 Cordyceps spp., 1 Drechmeria sp., and 10 Ophiocordyceps spp. (Table 2). They are mostly distributed in either Asia or Australia/New Zealand. After Hepialidae, Noctuidae and Sphingidae are the families mostly infected by Cordyceps spp. (Table 3).

Among heteroneuran families, Notodontidae, Drepanidae, and Lasiocampidae are known as hosts of C. militaris only (Table 3). Similarly, there are families identified as hosts for single Cordyceps/Ophiocordyceps spp., for example, Limacodidae (Cochlididae) for $O$. cochlidiicola, Tineidae for C. cardinalis, Papilionidae for $C$. tuberculata, and Pieridae for C. taii. In general, 11 families are known for just one or two Cordyceps spp. (Table 3). On the other hand, a single host species is infected by two spp. such as Clanis bilineata by Cordyceps kyusyuensis and C. taishanensis, Sphinx pinastri by C. militaris and C. tuberculata, Ahamus yunnanensis by Ophiocordyceps lanpingensis and O. laojunshanensis, and Endoclita nodus by $O$. ramosissimum and O. xuefengensis. From species richness point of view, Erebidae, Geometridae, and Noctuidae are the biggest families in Lepidoptera that occupy nearly $40 \%$ of the total lepidopterans [122]. However, they are reported with fewer Cordyceps pathogens. For instance, only two Cordyceps spp. are recorded on each Erebidae and Geometridae, proportionately more on Noctuidae (7 spp.) (Table 3). In addition to Coleoptera and Lepidoptera, C. militaris is recorded on two more orders Diptera and Hymenoptera [126]. Similarly, the only other species growing on two orders Lepidoptera and Coleoptera is C. nikkoensis.

The analysis in the present review is based on the coleopteran and lepidopteran hosts that are identified at family or infrafamily ranks in the literature. Out of estimated 200 spp. reported on coleopteran and lepidopteran hosts, we have enlisted $92 \mathrm{spp}$. based on their host records in the literature. We could not include the remaining species because of lack of information on infraorder ranks of their hosts. Though the list is not complete for all Coleoptera and lepidopteran hosts, the overall scenario of the taxonomic distributions of the hosts within Coleoptera and Lepidoptera can be viewed in the present review.

\section{Further Studies on Hosts of Cordyceps Pathogens}

Cordyceps fungi with attached hosts have long been studied as botanical or mycological specimens. Mycologists have studied and identified fungal pathogens of insects based on morphological, ecological, and phylogenetic studies [14, $50,128]$. For interested readers, several color books on entomopathogenic fungi are available [59, 129-142]. However, identification of the host species is far from being complete. Some of the possible reasons for the less work on host identification are discussed here. First, the diseased/damaged/deformed insect specimens hinder the objectives of the insect biologists to study their diversity and life cycle and thus are disposed immediately after encountering them [77]. Second, insects are mostly attacked at larval stage, making the identification more difficult and time consuming. Larval stages are not yet described in most of insect species. However, molecular techniques have been recently developed to identify immature stages of insects [143]. Third, Cordyceps pathogens of insects rarely cause epizootic outbreaks on their hosts, hence causing no significant economic or ecological losses. Fourth, finding a Cordyceps pathogen requires much experience and patience and is out of sight for normal observers. Fifth, Cordyceps pathogens are specialists; that is, they are host specific; hence experts interested in one group of insects need not care about pathogens on insects of noninterest groups.

Exploring the potential economic benefit from Cordyceps fungi is a continuous objective of mycologists in collaboration with biotechnologists, pharmacologists, analytical chemists, medical scientists, and so forth. The most common example is Ophiocordyceps sinensis. This is the fungal entomopathogen collected every year in large quantities [144-148] and sold worldwide as the most expensive biological resource almost twice the value of gold by weight and hence commonly known as Himalayan Gold [149], Tibetan Gold (http://mushroaming.com/content/yartsa-gunbu-article-national-geographic-magazine), or Biological Gold [147]. 
The other potential species is Cordyceps militaris that has been successfully grown on artificial media for commercial purpose [126]. Antitumour, antimetastatic, immunomodulatory, antioxidant, anti-inflammatory, insecticidal, antimicrobial, hypolipidaemic, hypoglycaemic, antiaging, neuroprotective, and renoprotective effects are some of the main effects shown by Cordyceps fungi [150].

Insect specimens, decaying or mummified with natural enemies, such as virus, bacteria, and fungi, are the good sources of biological control agents of specific insect groups, especially in agriculture, forests, and other natural communities. For example, the susceptible stages of hosts in nature could be informative for the application of entomopathogenic fungi to control harmful insect and pests.

In conclusion, we believe such reviews will attract wider audience towards economic and ecological benefits of entomopathogenic fungi including Cordyceps, paving the way for interdisciplinary collaborations. Such reviews will also generate interest in a wider audience including field entomologists, ecologists, biocontrol researchers, and biotechnologists in utilization of entomopathogenic fungi. The accumulative work on host information of other orders parasitized by Cordyceps and its asexual genera is going on with the objective of expanding the insect-fungal pathogen index in future.

\section{Conflict of Interests}

The authors declare that there is no conflict of interests regarding the publication of this paper.

\section{Acknowledgments}

This work was supported by the research program of agricultural science and technology development (PJ008523) of the National Institute of Horticultural and Herbal Science and by Korea National Arboretum (Project no. KNA 1-1-10).

\section{References}

[1] D. W. Roberts and R. A. Humber, "Entomogenous fungi," in Biology of Conidial Fungi Vol 2, G. T. Cole and B. Kendrick, Eds., pp. 201-236, Academic Press, New York, NY, USA, 1981.

[2] C. W. McCoy, R. A. Samson, and D. G. Boucias, "Entomogenous fungi," in Handbook of Natural Pesticides Vol 5, Microbial Insecticides (Part A), Entomogenous Protozoa and Fungi, C. M. Ignoffo, Ed., pp. 151-236, CRC Press, Boca Raton, Fla, USA, 1988.

[3] H. C. Evans, S. L. Elliot, and D. P. Hughes, "Ophiocordyceps unilateralis: a keystone species for unraveling ecosystem functioning and biodiversity of fungi in tropical forests?" Communicative \& Integrative Biology, vol. 4, no. 5, pp. 598-602, 2011.

[4] F. E. Vega, N. V. Meyling, J. J. Luangsa-ard, and M. Blackwell, "Fungal entomopathogens," in Insect Pathology, F. E. Vega and H. K. Kaya, Eds., pp. 171-220, Academic Press, London, UK, 2nd edition, 2012.

[5] A. Augustyniuk-Kram and K. J. Kram, "Entomopathogenic fungi as an important natural regulator of insect outbreaks in forests (review)," in Forest Ecosystems-More than Just Trees, J.
A. Blanco and Y.-H. Lo, Eds., chapter 12, pp. 265-294, InTech, Rijeka, Croatia, 2012.

[6] H. D. Burges, "Strategy for the microbal control of pests in 1980 and beyond," in Microbial Control of Pests and Plant Diseases 1970-1980, H. D. Burges, Ed., pp. 797-836, Academic Press, London, UK, 1981.

[7] H. C. Evans, "Entomogenous fungi in tropical forest ecosystems: an appraisal," Ecological Entomology, vol. 7, no. 1, pp. 4760, 1982.

[8] B. Shrestha, E. Tanaka, J.-G. Han et al., "A Brief chronicle of the genus Cordyceps Fr., the oldest valid genus in Cordycipitaceae (Hypocreales, Ascomycota)," Mycobiology, vol. 42, no. 2, pp. 9399, 2014.

[9] B. Shrestha, W. Zhang, Y. Zhang, and X. Liu, "What is the Chinese caterpillar fungus Ophiocordyceps sinensis (Ophiocordycipitaceae)?" Mycology, vol. 1, no. 4, pp. 228-236, 2010.

[10] S. Shrestha, B. Shrestha, J. H. Park, D. Y. Lee, J. G. Cho, and N. I. Baek, "Chemical constituents of Yarsagumba (Ophiocordyceps sinensis (Berk.) Sung et al.), a valued traditional Himalayan medicine," Nepal Journal of Science and Technology, vol. 13, no. 1, pp. 43-58, 2012.

[11] S. Shrestha, A. K. Shrestha, J. H. Park et al., "Review on pharmacologically active metabolites from Yarsagumba (Ophiocordyceps sinensis), an epitome of Himalayan elixir," Nepal Journal of Science and Technology, vol. 14, no. 2, pp. 49-58, 2013.

[12] B. Shrestha, "Yarsagumba: fungal biology and medicinal value," in Environment and Natural Resources, P. K. Jha, F. P. Neupane, M. L. Shrestha, and I. P. Khanal, Eds., pp. 607-610, Nepal Academy of Science and Technology, Khumaltar, Nepal, 2013.

[13] B. Baral, B. Shrestha, and J. A. T. da Silva, "A review of Chinese Cordyceps with special reference to Nepal, focusing on conservation," Environmental and Experimental Biology, vol. 13, no. 2, pp. 61-73, 2015.

[14] G.-H. Sung, N. L. Hywel-Jones, J.-M. Sung, J. J. Luangsa-ard, B. Shrestha, and J. W. Spatafora, "Phylogenetic classification of Cordyceps and the clavicipitaceous fungi," Studies in Mycology, vol. 57, pp. 5-59, 2007.

[15] S. Artjariyasripong, J. I. Mitchell, N. L. Hywel-Jones, and E. B. G. Jones, "Relationship of the genus Cordyceps and related genera, based on parsimony and spectral analysis of partial $18 \mathrm{~S}$ and $28 \mathrm{~S}$ ribosomal gene sequences," Mycoscience, vol. 42, no. 6, pp. 503517, 2001.

[16] Ø. Stensrud, N. L. Hywel-Jones, and T. Schumacher, “Towards a phylogenetic classification of Cordyceps: ITS nrDNA sequence data confirm divergent lineages and paraphyly," Mycological Research, vol. 109, no. 1, pp. 41-56, 2005.

[17] J. W. Spatafora, G.-H. Sung, J.-M. Sung, N. L. Hywel-Jones, and J. F. White Jr., "Phylogenetic evidence for an animal pathogen origin of ergot and the grass endophytes," Molecular Ecology, vol. 16, no. 8, pp. 1701-1711, 2007.

[18] G.-H. Sung, J.-M. Sung, N. L. Hywel-Jones, and J. W. Spatafora, "A multi-gene phylogeny of Clavicipitaceae (Ascomycota, Fungi): identification of localized incongruence using a combinational bootstrap approach," Molecular Phylogenetics and Evolution, vol. 44, no. 3, pp. 1204-1223, 2007.

[19] R. M. Kepler, G.-H. Sung, Y. Harada et al., "Host jumping onto close relatives and across kingdoms by Tyrannicordyceps (Clavicipitaceae) gen. nov. and Ustilaginoidea (Clavicipitaceae)," American Journal of Botany, vol. 99, no. 3, pp. 552-561, 2012. 
[20] C. A. Quandt, R. M. Kepler, W. Gams et al., "Phylogenetic-based nomenclatural proposals for Ophiocordycipitaceae (Hypocreales) with new combinations in Tolypocladium," IMA Fungus, vol. 5, no. 1, pp. 121-134, 2014.

[21] R. M. Kepler, R. A. Humber, J. F. Bischoff, and S. A. Rehner, "Clarification of generic and species boundaries for Metarhizium and related fungi through multigene phylogenetics," Mycologia, vol. 106, no. 4, pp. 811-829, 2014.

[22] J. W. Spatafora, C. A. Quandt, R. M. Kepler et al., "New 1F1N species combinations in Ophiocordycipitaceae (Hypocreales)," IMA Fungus, vol. 6, no. 2, pp. 357-362, 2015.

[23] K. Keissler and H. Lohwag, "Part II fungi," in Symbolae Sinicae, H. Handel-Mazzetti, Ed., pp. 1-73, Springer, Wien, Germany, 1937.

[24] E. McLennan and I. Cookson, "Additions to Australian ascomycetes, no. 2," Proceedings of the Royal Society of Victoria, vol. 38, pp. 69-76, 1926.

[25] M. Shimazu, W. Mitsuhashi, and H. Hashimoto, "Cordyceps brongniartii sp. nov., the teleomorph of Beauveria brongniartii," Transactions of the Mycological Society of Japan, vol. 29, pp. 323330, 1988.

[26] A. S. Olliff, "Australian entomophytes or entomogenous fungi," Agricultural Gazett of New South Wales, vol. 6, pp. 402-414, 1895.

[27] T. Petch, "Notes on entomogenous fungi," Transactions of the British Mycological Society, vol. 21, no. 1-2, pp. 34-67, 1937.

[28] S. C. Teng, "Notes on hypocreales from China," Sinensia, vol. 4, no. 10, pp. 269-298, 1934.

[29] G. Massee, "Révision du genre Cordyceps," Revue Mycologique, vol. 21, pp. 1-16, 1899.

[30] M. C. Cooke, Vegetable Wasps and Plant Worms, Society for Promoting Christian Knowledge, London, UK, 1892.

[31] V. Y. Kryukov, O. N. Yaroslavtseva, G. R. Lednev, and B. A. Borisov, "Local epizootics caused by teleomorphic cordycipitoid fungi (Ascomycota: Hypocreales) in populations of forest lepidopterans and sawflies of the summer-autumn complex in Siberia," Microbiology, vol. 80, no. 2, pp. 286-295, 2011.

[32] A. de Bary, "Zur Kenntniss insectentoedtender pilze," Botanische Zeitung, vol. 25, pp. 2-28, 1867.

[33] Y. Kobayasi and D. Shimizu, "Cordyceps species from Japan 6," Bulletin of the National Science Museum, Tokyo B, Botany, vol. 9, no. 1, pp. 1-21, 1983.

[34] P. S. Negi, R. Singh, P. S. Koranga, and Z. Ahmed, "Two new for science species of genus Cordyceps Fr. (Ascomycetes) from Indian Himalaya," International Journal of Medicinal Mushrooms, vol. 14, no. 5, pp. 501-506, 2012.

[35] Y. Kobayasi and D. Shimizu, "Cordyceps species from Japan 5," Bulletin of the National Science Museum, Tokyo Series B: Botany, vol. 8, no. 4, pp. 111-123, 1982.

[36] J. Moureau, “Cordyceps du Congo Belge," Mémoires de l'Institut Royal Colonial Belge, vol. 7, no. 5, pp. 1-58, 1949.

[37] A. Möller, Phycomyceten und Ascomyceten, Untersuchungen aus Brasilien, Botanische Mittheilungen aus den Tropen 9, edited by A. F. W. Schimper, Gustav Fischer, Jena, Germany, 1901.

[38] Y. Kobayasi and D. Shimizu, "The genus Cordyceps and its allies from New Guinea," Bulletin of the National Science Museum, Tokyo Series B: Botany, vol. 2, no. 4, pp. 133-152, 1976.

[39] B. Liu, F. Rong, and H. Jin, "A new species of the Genus Cordyceps," Journal of Wuhan Botanical Research, vol. 3, no. 1, pp. 23-24, 1985.
[40] Y. Kobayasi and D. Shimizu, "Cordyceps species from Japan 4," Bulletin of the National Science Museum, Tokyo, B, Botany, vol. 8, no. 3, pp. 79-91, 1982.

[41] G. Massee, "A revision of the genus Cordyceps," Annals of Botany, vol. 9, no. 33, pp. 1-44, 1895.

[42] Z. Y. Liu, Z. Q. Liang, A. J. S. Whalley, Y.-J. Yao, and A. Y. Liu, "Cordyceps brittlebankisoides, a new pathogen of grubs and its anamorph, Metarhizium anisopliae var. majus," Journal of Invertebrate Pathology, vol. 78, no. 3, pp. 178-182, 2001.

[43] W. M. Zhang, T. H. Li, V. Q. Chen, and L. H. Qu, "Cordyceps campsosterna, a new pathogen of Campsosternus auratus," Fungal Diversity, vol. 17, pp. 239-242, 2004.

[44] C. L. Spegazzini, "Reliquiae mycologicae tropicae et fungi costaricenses nonnulli," Boletin de la Academia Nacional de Ciencias en Córdoba, vol. 23, pp. 365-609, 1919.

[45] J. Mathieson, "Cordyceps aphodii, a new species, on pasteur cockchafer grubs," Transactions of the British Mycological Society, vol. 32, no. 2, pp. 113-135, 1949.

[46] T. R. Glare, M. O'Callaghan, and P. J. Wigley, "Checklist of naturally occurring entomopathogenic microbes and nematodes in New Zealand," New Zealand Journal of Zoology, vol. 20, no. 2, pp. 95-120, 1993.

[47] S. C. Teng, "Additional fungi from China IV," Sinensia, vol. 7, no. 6, pp. 752-823, 1936.

[48] N. L. Hywel-Jones, “Cordyceps brunneapunctata sp. nov. infecting beetle larvae in Thailand," Mycological Research, vol. 99, no. 10, pp. 1195-1198, 1995.

[49] Y. Kobayasi and D. Shimizu, "Cordyceps species from Japan 2," Bulletin of the National Science Museum, Tokyo, B, Botany, vol. 6, no. 3, pp. 77-96, 1980.

[50] Y. Kobayasi, “The genus Cordyceps and its allies," Science Reports of the Tokyo Bunrika Daigaku B, vol. 5, no. 84, pp. 53-260, 1941.

[51] Y. Kobayasi and D. Shimizu, "Cordyceps species from Japan 3," Bulletin of the National Science Museum, Tokyo, Series B: Botany, vol. 6, no. 4, pp. 125-145, 1980.

[52] V. Kautman and I. Kautmanová, "Cordyceps s.l. (ascomycetes, clavicipitaceae) in Slovakia," Catathelasma, vol. 11, pp. 5-48, 2009.

[53] I. Kautmanová, "Cordyceps entomorrhiza and Cordyceps tuberculata (Ascomycetes, Clavicipitales) new for Slovakia," Acta Rerum naturalium Musei Nationalis Slovaci Bratislava, vol. 48, pp. 40-43, 2002.

[54] I. Klingen, S. H. Salinas, and R. Meadow, "Checklist of naturally occurring pathogens of insects and mites in Norway," Norwegian Journal of Entomology, vol. 49, no. 1, pp. 23-28, 2002.

[55] Y. Kobayasi, "On the specific connection of Cordyceps entomorrhiza and Tilachlidiopsis nigra," Shokubutsugaku Zasshi, vol. 51, no. 603, pp. 97-102, 1937.

[56] J. M. Moingeon, "Réflexions sur le genre Cordyceps," Bulletin de la Société mycologique de France, vol. 119, no. 1-2, pp. 117-132, 2003.

[57] M. Zang and N. Kinjo, "Notes on the alpine Cordyceps of China and nearby nations," Mycotaxon, vol. 66, pp. 215-229, 1998.

[58] C. R. Li, M. Z. Fan, B. Huang, S. B. Wang, and Z. Z. Li, "The genus Cordyceps and its allies from Anhui I," Mycosystema, vol. 21, no. 2, pp. 167-171, 2002.

[59] N. Yahagi, "Illustrated catalogue of Japanese Cordyceps (entomonogenous fungi): the Yahagi collection of Japanese Cordyceps stored in the Tohoku University Museum," Bulletin of the Tohoku University Museum, no. 8, pp. 29-89, 2008. 
[60] T. I. Sanjuan, A. E. Franco-Molano, R. M. Kepler et al., "Five new species of entomopathogenic fungi from the Amazon and evolution of neotropical Ophiocordyceps," Fungal Biology, vol. 119, no. 10, pp. 901-916, 2015.

[61] Z. L. Yang, J. Qin, C. Xia, Q. Hu, and Q. Q. Li, “Ophiocordyceps highlandensis, a new entomopathogenic fungus from Yunnan, China," Phytotaxa, vol. 204, no. 4, pp. 287-295, 2015.

[62] Z. Q. Liang, A. Y. Liu, and Y. C. Jiang, "Two new species of Cordyceps from Jinggang Mountains," Mycosystema, vol. 20, no. 3, pp. 306-309, 2001.

[63] E. Z. Koval, Opredelitel Entomofilnych Gribov CCCP, Science Academy of Ukraine, Kiev, Ukraine, 1974.

[64] Y. Kobayasi, "Miscellaneous notes on the genus Cordyceps and its allies (2)," Journal of Japanese Botany, vol. 52, no. 3, pp. 65-71, 1977.

[65] J. B. Ellis and B. M. Everhart, The North American Pyrenomycetes, Ellis \& Everhart, Newfield, NJ, USA, 1892.

[66] J. J. Roth and P. Clerc, "Cordyceps michiganensis Mains (Ascomycètes, Clavicipitales), ouvel ascomycète pour l'Europe," Mycologia Helvetica, vol. 9, no. 1, pp. 29-37, 1997.

[67] M. J. Berkeley, “On some entomogenous Sphaeriae," Journal of the Proceedings of the Linnean Society. Botany, vol. 1, no. 4, pp. 157-159, 1857.

[68] E. B. Mains, "North American entomogenous species of Cordyceps," Mycologia, vol. 50, no. 2, pp. 169-222, 1958.

[69] E. B. Mains, "New and interesting species of Cordyceps," Mycologia, vol. 39, no. 5, pp. 535-545, 1947.

[70] T. R. Glare, "Hirsutella stylophora Mains, a pathogen of Costelytra zealandica (Coleoptera: Scarabaeidae) in New Zealand," New Zealand Entomologist, vol. 15, no. 1, pp. 29-32, 1992.

[71] M. F. Moniz, M. T. Cabral, I. L. Tomaz, and M. S. Basto, "On the appearance of a mycosis in Phoracantha semipunctata (Fab.) larva," Silva Lusitana, vol. 7, no. 1, pp. 49-54, 1999.

[72] C. MacMillan, "Cordyceps stylophora Berk. \& Br. in Minnesota," Bulletin of the Torrey Botanical Club, vol. 25, p. 583, 1898.

[73] J. Mornand, G. Girod, and R. Péan, "Les Cordyceps entomophiles en Europe," http://www.ascofrance.com/uploads/document/Catalogue-Cordyceps-suite-3-0001.pdf.

[74] A. E. Hajek, "Ecology of terrestrial fungal entomopathogens," Advances in Microbial Ecology, vol. 15, pp. 193-249, 1997.

[75] G.-H. Sung, B. Shrestha, S.-K. Han, and J.-M. Sung, "Growth and cultural characteristics of Ophiocordyceps longissima collected in Korea," Mycobiology, vol. 39, no. 2, pp. 85-91, 2011.

[76] T.-C. Wen, R.-C. Zhu, J.-C. Kang et al., "Ophiocordyceps xuefengensis sp. nov. from larvae of Phassus nodus (Hepialidae) in Hunan Province, southern China," Phytotaxa, vol. 123, no. 1, pp. 41-50, 2013.

[77] H. C. Evans, "Fungal pathogens of spiders," in Spider Ecophysiology Part III, W. Nentwig, Ed., pp. 107-121, Springer, Berlin, Germany, 2013.

[78] S. B. Andersen, S. Gerritsma, K. M. Yusah et al., "The life of a dead ant: the expression of an adaptive extended phenotype," The American Naturalist, vol. 174, no. 3, pp. 424-433, 2009.

[79] D. P. Hughes, S. B. Andersen, N. L. Hywel-Jones, W. Himaman, J. Billen, and J. J. Boomsma, "Behavioral mechanisms and morphological symptoms of zombie ants dying from fungal infection," BMC Ecology, vol. 11, article 13, 2011.

[80] D. P. Hughes, T. Wappler, and C. C. Labandeira, "Ancient deathgrip leaf scars reveal ant-fungal parasitism," Biology Letters, vol. 7, no. 1, pp. 67-70, 2011.
[81] C. de Bekker, L. E. Quevillon, P. B. Smith et al., "Species-specific ant brain manipulation by a specialized fungal parasite," $B M C$ Evolutionary Biology, vol. 14, no. 1, article 166, 2014.

[82] R. A. Samson, H. C. Evans, and J. Latgé, Atlas of Entomopathogenic Fungi, Springer, Utrecht, The Netherlands, 1988.

[83] H. E. Roy, D. C. Steinkraus, J. Eilenberg, A. E. Hajek, and J. K. Pell, "Bizarre interactions and endgames: entomopathogenic fungi and their arthropod hosts," Annual Review of Entomology, vol. 51, pp. 331-357, 2006.

[84] S. A. Ślipiński, R. A. B. Leschen, and J. F. Lawrence, "Order Coleoptera Linnaeus, 1758," in Animal Biodiversity: An Outline of Higher-Level Classification and Survey of Taxonomic Richness, Z. Q. Zhang, Ed., vol. 3148, pp. 203-208, Zootaxa, 2011.

[85] L. Bocak, C. Barton, A. Crampton-Platt, D. Chesters, D. Ahrens, and A. P. Vogler, "Building the Coleoptera tree-of-life for $>8000$ species: composition of public DNA data and fit with Linnaean classification," Systematic Entomology, vol. 39, no. 1, pp. 97-110, 2014.

[86] J. H. Willis, "Australian species of the fungal genus Cordyceps (Fr.) link with critical notes on collection in Australian herbaria," Muelleria, vol. 1, pp. 68-89, 1959.

[87] G. Palfner, V. Valenzuela-Muñoz, C. Gallardo-Escarate, L. E. Parra, J. Becerra, and M. Silva, "Cordyceps cuncunae (Ascomycota, Hypocreales), a new pleoanamorphic species from temperate rainforest in southern Chile," Mycological Progress, vol. 11, no. 3, pp. 733-739, 2012.

[88] J.-S. Lim, S.-H. Kim, J.-Y. Choi, J.-S. Park, S. J. Park, and K.S. Shin, "Cytokine-inducing and T Cell mitogenic effects of Cordyceps hepialidicola," Journal of Microbiology, vol. 39, no. 3, pp. 181-185, 2001.

[89] T. Petch, "A revised list of British entomogenous fungi," Transactions of the British Mycological Society, vol. 31, no. 3-4, pp. 286304, 1948.

[90] M. Zang, D. Yang, and C. Li, "A new taxon in the genus Cordyceps from China," Mycotaxon, vol. 37, pp. 57-62, 1990.

[91] A. Liu, Z. Liang, and Z. Liu, "Cordyceps spp. and some other entomopathogenic fungi from the Emei Mountain preserve in China," Mycosystema, vol. 16, no. 2, pp. 139-143, 1997.

[92] E. M. Lauritzen, “Cordyceps gracilis Montagne \& Durieu new to Scandinavia," Blyttia, vol. 29, no. 2, pp. 85-87, 1971.

[93] M. J. Berkeley, "Nat. Ord. CII. Fungi," in The Botany of the Antarctic Voyage. II. Florae Novae-Zealandiae, J. D. Hooker, Ed., pp. 172-210, Lovell Reeve, London, UK, 1855.

[94] D. Miller, "The insect people of the Maori," The Journal of the Polynesian Society, vol. 61, no. 1-2, pp. 1-61, 1952.

[95] Z. Zou, X. Liu, and G. Zhang, "Revision of taxonomic system of the genus Hepialus (Lepidoptera: Hepialidae) currently adopted in China," Journal of Hunan University of Science and Technology (Natural Science Edition), vol. 25, no. 1, pp. 114-120, 2010.

[96] X.-L. Wang and Y.-J. Yao, "Host insect species of Ophiocordyceps sinensis: a review," ZooKeys, vol. 127, pp. 43-59, 2011.

[97] Z.-H. Chen, Y.-D. Dai, H. Yu et al., "Systematic analyses of Ophiocordyceps lanpingensis sp. nov., a new species of Ophiocordyceps in China," Microbiological Research, vol. 168, no. 8, pp. 525-532, 2013.

[98] J.-Y. Chen, Y.-Q. Cao, D.-R. Yang, and M.-H. Li, "A new species of Ophiocordyceps (Clavicipitales, Ascomycota) from southwestern China," Mycotaxon, vol. 115, pp. 1-4, 2011.

[99] T.-C. Wen, Y.-P. Xiao, W.-J. Li, J.-C. Kang, and K. D. Hyde, "Systematic analyses of Ophiocordyceps ramosissimum sp. nov., a new species from a larvae of Hepialidae in China," Phytotaxa, vol. 161, no. 3, pp. 227-234, 2014. 
[100] Z. Li, C. Li, B. Huang, and M. Fan, "Discovery and demonstration of the teleomorph of Beauveria bassiana (Bals.) Vuill., an important entomogenous fungus," Chinese Science Bulletin, vol. 46, no. 9, pp. 751-753, 2001.

[101] O. Eriksson, "Cordyceps bifusispora spec. nov." Mycotaxon, vol. 15, pp. 185-188, 1982.

[102] G.-H. Sung and J. W. Spatafora, "Cordyceps cardinalis sp. nov., a new species of Cordyceps with an east Asian-eastern North American distribution," Mycologia, vol. 96, no. 3, pp. 658-666, 2004.

[103] S. Kawamura, Icones of Japanese Fungi, vol. 8, Kazama Shobó, Tokyo, Japan, 1955.

[104] P. C. Hennings, "Einige neue Cordiceps-arten aus Surinam," Hedwigia, vol. 41, pp. 167-169, 1902.

[105] H. S. Gu and M. Y. Liang, "Study on the manual cultivation of Cordyceps militaris," Pharmaceutical Information Bulletin, vol. 5, no. 3, pp. 51-52, 1987.

[106] A. Panigrahi, "Fungus Cordyceps militaris infestation in the pupa of the tea pest Andraca bipunctata Walker," Environment and Ecology, vol. 13, pp. 942-946, 1995.

[107] T. Ulvinen, "Hyönteisissä elävistä Cordyceps-lajeista eräistä kuroma-asteisista sienistä. Pikkutietoja-Notulae," Annales Entomologici Fennici, vol. 35, pp. 234-237, 1969.

[108] T. Lagerberg, "Smärre meddelanden: Cordiceps militaris (L.) Link i Sverige," Svensk Botanisk Tidskrift, vol. 16, pp. 285-290, 1922.

[109] Q. W. Chen, "Study on Cordyceps (Fr.) fungi in Shennongjia forest district," Hubei Agricultural Sciences, vol. 6, pp. 49-52, 1997.

[110] O. J. Sopp, Untersuchungen Über Insekten-Vertilgende Pilze Bei den Letzten Kieferspinnerepidemien in Norwegen, vol. 2 of Skrift Vidensk-Selsk I. Mat-Naturv Klasse, Christiania, Norway, 1911.

[111] G. R. Gray, Notices of Insects That are Known to Form the Bases of Fungoid Parasites, Harvard University, London, UK, 1858.

[112] H. Sato, M. Shimazu, and N. Kamata, "Detection of Cordyceps militaris Link (Clavicipitales: Clavicipitaceae) by burying pupae of Quadricalcarifera punctatella Motschulsky (Lepidoptera: Notodontidae," Applied Entomology and Zoology, vol. 29, no. 1, pp. 130-132, 1994.

[113] S. W. Hitchcock, "Pupal mortality of the orange-striped oakworm," Journal of Economic Entomology, vol. 54, no. 5, pp. 962964, 1961.

[114] G. Pacioni and W. Rossi, "Nuove segnalazioni di funghi entomogeni," Giornale Botanico Italiano, vol. 114, no. 3-4, pp. 169$174,1980$.

[115] B. Liu, P. Yuan, and J. Cao, "A new species of Cordyceps from China," Acta Mycologica Sinica, vol. 3, no. 4, pp. 192-195, 1984.

[116] T. Petch, "Contributions to the flora of tropical America: XX. Entomogenous fungi from British Guiana," Bulletin of Miscellaneous Information (Royal Botanic Gardens, Kew), vol. 1934, no. 5, pp. 202-205, 1934.

[117] H. Lebert, "Ueber einige neue oder unvollkommen gekannte Krankheiten der Insekten, welche durch Entwicklung niederer," Zeitschrift fur Wissenschaftliche Zoologie, vol. 9, pp. 439-453, 1858.

[118] R. Maire, "Champignons Nord-Africains nouveaux ou peu connus," Bulletin de la Société d'Histoire Naturelle de l'Afrique du Nord, vol. 8, no. 7, pp. 134-200, 1917.

[119] Y. Kobayasi and D. Shimizu, "Cordyceps species from Japan," Bulletin of the National Science Museum, Tokyo B, Botany, vol. 4, no. 2, pp. 43-63, 1978.
[120] S. Ban, T. Sakane, and A. Nakagiri, "Three new species of Ophiocordyceps and overview of anamorph types in the genus and the family Ophiocordyceptaceae," Mycological Progress, vol. 14, no. 1, article 1017, 2015.

[121] K. J. Gaston, "The magnitude of global insect species richness," Conservation Biology, vol. 5, no. 3, pp. 283-296, 1991.

[122] E. J. van Nieukerken, L. Kaila, I. J. Kitching et al., "Order Lepidoptera Linnaeus, 1758," in Animal Biodiversity: An Outline of Higher-Level Classification and Survey of Taxonomic Richness, Z. Q. Zhang, Ed., vol. 3148, pp. 212-221, Zootaxa, 2011.

[123] D. L. Wagner, "Moths," in Encyclopedia of Biodiversity, S. A. Levin, Ed., pp. 249-270, Academic Press, San Diego, Calif, USA, 2001.

[124] C. A. Edwards, "The bionomics of swift moths. I.- the ghost swift moth, Hepialus humuli (L.)," Bulletin of Entomological Research, vol. 55, no. 1, pp. 147-160, 1964.

[125] J. R. Grehan, "Larval feeding habits of the Hepialidae (Lepidoptera)," Journal of Natural History, vol. 23, no. 4, pp. 803-824, 1989.

[126] B. Shrestha, W. Zhang, Y. Zhang, and X. Liu, "The medicinal fungus Cordyceps militaris: research and development," Mycological Progress, vol. 11, no. 3, pp. 599-614, 2012.

[127] B. Shrestha, H.-K. Kim, G.-H. Sung, J. W. Spatafora, and J.M. Sung, "Bipolar heterothallism, a principal mating system of Cordyceps militaris in vitro," Biotechnology and Bioprocess Engineering, vol. 9, no. 6, pp. 440-446, 2004.

[128] Y. Kobayasi, "Keys to the taxa of the genera Cordyceps and Torrubiella," Transactions of the Mycological Society of Japan, vol. 23, pp. 329-364, 1982.

[129] Y. Kobayasi and D. Shimizu, Iconography of Vegetable Wasps and Plant Worms, Hoikusha Publishing Co., Osaka, Japan, 1983.

[130] J. M. Sung, The Insect-Borne Fungus of Korea in Color, Kyohak, Seoul, South Korea, 1996.

[131] D. Shimizu, Illustrated Vegetable Wasps and Plant Worms in Colour, Ie-No-Hikari Association, Tokyo, Japan, 1997.

[132] S. S. Tzean, L. S. Hsieh, and W. J. Wu, Atlas of Entomopathogenic Fungifrom Taiwan, Council of Agriculture, Taipei, Taiwan, 1997.

[133] J. J. Luangsa-ard, K. Tasanathai, S. Mongkolsamrit, and N. L. Hywel-Jones, Atlas of Invertebrate-Pathogenic Fungi of Thailand, vol. 1, National Center for Genetic Engineering and Biotechnology, National Science and Technology Development Agency, Pathum Thani, Thailand, 2007.

[134] J. J. Luangsa-ard, K. Tasanathai, S. Mongkolsamrit, and N. L. Hywel-Jones, Atlas of Invertebrate-Pathogenic Fungi of Thailand Vol 2, National Center for Genetic Engineering and Biotechnology, National Science and Technology Development Agency, Pathum Thani, Thailand, 2008.

[135] M. Moriguchi and M. Yasuda, The Handbook of Vegetable Wasps and Plant Worms in Japan, Bunichi-Sougou Shuppan, Tokyo, Japan, 2009.

[136] Z. Liang, Z. Liu, Y. Han, and A. Liu, Atlas of Cordyceps in China, Guizhou Ke Ji Chu Ban She, Guiyang Shi, China, 2009.

[137] J. J. Luangsa-ard, K. Tasanathai, S. Mongkolsamrit, and N. L. Hywel-Jones, Atlas of Invertebrate-Pathogenic Fungi of Thailand, vol. 3, National Center for Genetic Engineering and Biotechnology, National Science and Technology Development Agency, Pathum Thani, Thailand, 2010.

[138] S. Mongkolsamrit, J. J. Luangsa-ard, K. Tasanathai, and S. Sivichai, Invertebrate-Pathogenic Fungi of Thailand, National Center for Genetic Engineering and Biotechnology, National Science and Technology Development Agency, Pathum Thani, Thailand, 2010. 
[139] T. Sakane and S. Ban, "Cordyceps and related fungi collected in Takatsuki, Osaka Prefecture," Bulletin of the Osaka Museum of Natural History, vol. 65, pp. 77-89, 2011.

[140] J. J. Luangsa-ard, K. Tasanathai, S. Mongkolsamrit, and N. L. Hywel-Jones, Atlas of Invertebrate-Pathogenic Fungi of Thailand Vol 4, National Center for Genetic Engineering and Biotechnology, National Science and Technology Development Agency, Pathum Thani, Thailand, 2012.

[141] Y. Okuzawa, Cultural History of Vegetable Wasps and Plant Worms, Ishida Taiseisha, Kyoto, Japan, 2012.

[142] An Illustrated Guide to Ecology of Japanese Cordyceps, Japanese Society of Cordyceps Research, Tokyo, Japan, 2014.

[143] K. Sasakawa, "A novel technique for identifying the instar of field-collected insect larvae," PLoS ONE, vol. 8, no. 2, Article ID e57836, 2013.

[144] S. Devkota, "Approach towards the harvesting of Cordyceps sinensis (Berk.) Sacc. in pastures of Dolpa, Nepal," in Medicinal Plants in Nepal: An Anthology of Contemporary Research, P. K. Jha, S. B. Karmacharya, M. K. Chetri, C. B. Thapa, and B. B. Shrestha, Eds., pp. 90-96, Ecological Society (ECOS), Kathmandu, Nepal, 2008.

[145] D. Winkler, "Yartsa Gunbu (Cordyceps sinensis) and the fungal commodification of Tibet's rural economy," Economic Botany, vol. 62, no. 3, pp. 291-305, 2008.

[146] U. B. Shrestha and K. S. Bawa, "Trade, harvest, and conservation of caterpillar fungus (Ophiocordyceps sinensis) in the Himalayas," Biological Conservation, vol. 159, pp. 514-520, 2013.

[147] U. B. Shrestha and K. S. Bawa, "Economic contribution of Chinese caterpillar fungus to the livelihoods of mountain communities in Nepal," Biological Conservation, vol. 177, pp. 194-202, 2014.

[148] B. B. Thapa, S. Panthi, R. K. Rai et al., "An assessment of Yarsagumba (Ophiocordyceps sinensis) collection in Dhorpatan Hunting Reserve, Nepal," Journal of Mountain Science, vol. 11, no. 2, pp. 555-562, 2014.

[149] R. Gould, "Himalayan Viagra, Himalayan Gold? Cordyceps sinensis brings new forces to the Bhutanese Himalaya," Tropical Resources Bulletin, vol. 26, pp. 63-69, 2007.

[150] T. B. Ng and H. X. Wang, "Pharmacological actions of Cordyceps, a prized folk medicine," Journal of Pharmacy and Pharmacology, vol. 57, no. 12, pp. 1509-1519, 2005. 

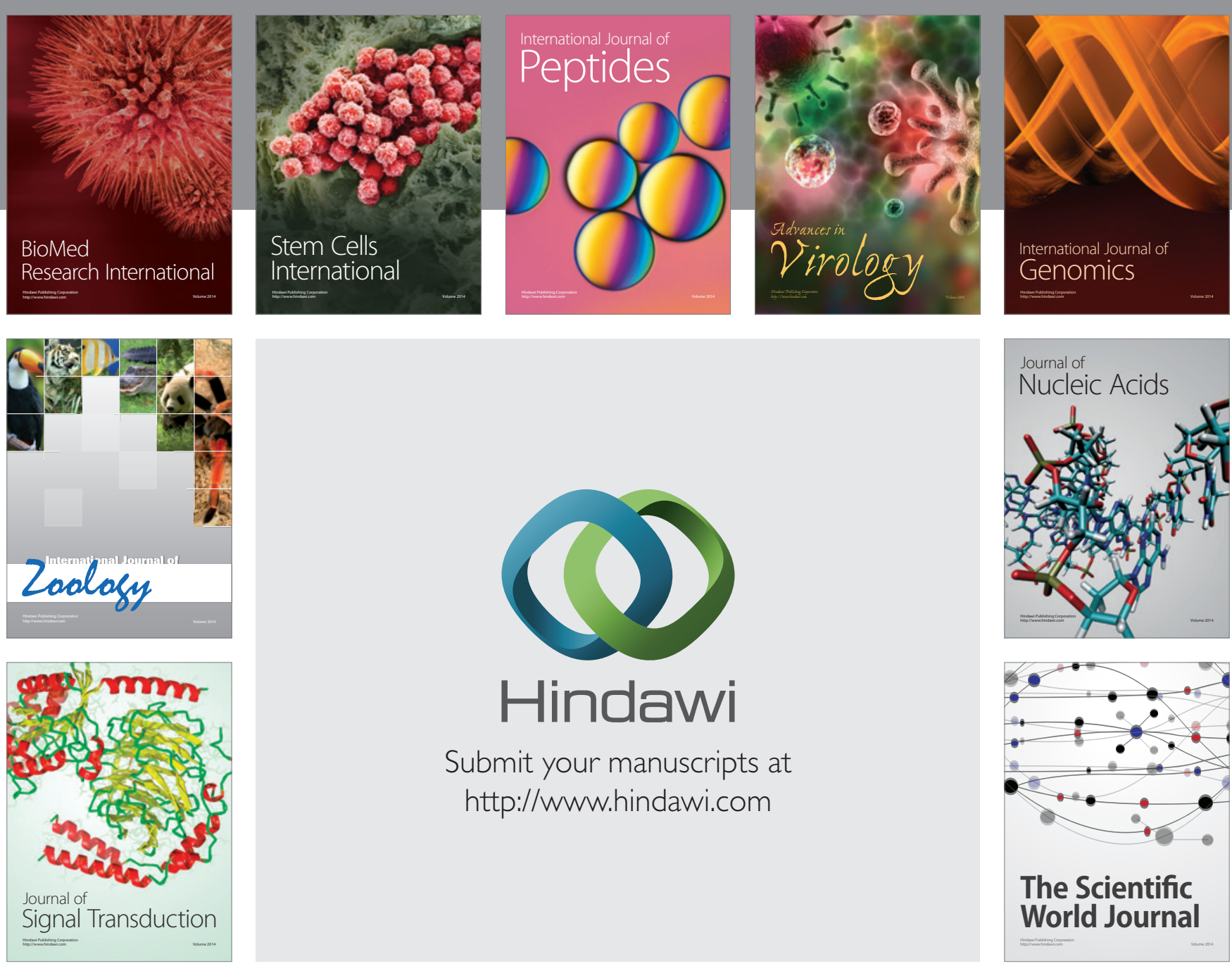

Submit your manuscripts at

http://www.hindawi.com
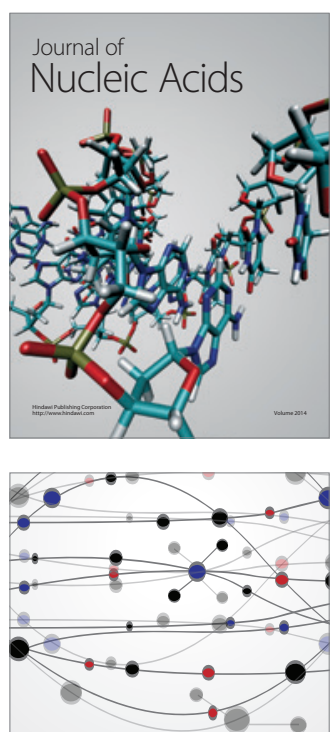

The Scientific World Journal
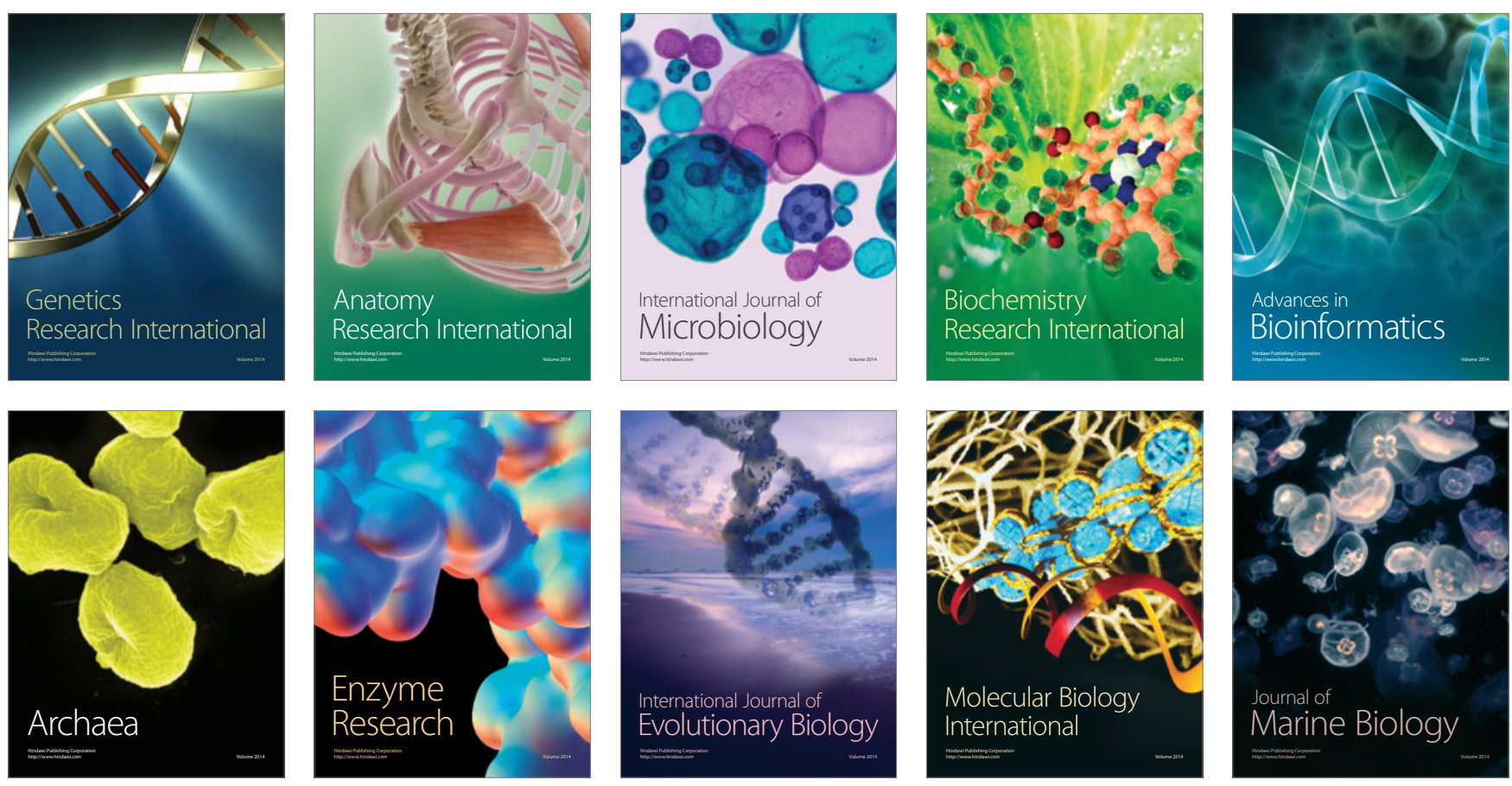